\title{
ANALISIS FAKTOR YANG MEMPENGARUHI PRODUKSI PADI SALIBU DAERAH SUMATERA BARAT
}

\author{
Rahmi Awalina, Delvi Yanti, dan Fadli Irsyad \\ Program Studi Teknik Pertanian dan Biosistem, Fakultas Teknologi Pertanian, Universitas Andalas \\ Email: rahmiawalina@ae.unand.ac.id
}

\begin{abstract}
ABSTRAK
Pada budidaya padi salibu ada beberapa faktor yang berpengaruh antara lain; 1) tinggi pemotongan batang sisa panen, 2) varietas, 3) kondisi air tanah setelah panen, dan 4) pemupukan. Penelitian ini bertujuan untuk menganalisis faktor yang mempengaruhi produksi padi salibu pada daerah Sumatera Barat. Pengumpulan data dilakukan melalui metode survai dan pengamatan langsung di lapangan. Pengamatan dilakukan terhadap kondisi air tanah setelah panen, tinggi pemotongan batang padi sisa panen, varietas, dan produksi lahan. Lokasi penelitian adalah beberapa daerah di Propinsi Sumatera Barat yang diambil secara acak. Data hasil pengamatan dianalisis sidik ragamnya yaitu one way anova dengan post test uji Duncan pada taraf $\alpha=0.05$. Hasil yang diperoleh pada penelitian ini yaitu waktu panen dan tinggi potongan batang padi sisa panen berpengaruh nyata terhadap jumlah anakan padi salibu. Kondisi air tanah pada saat panen berpengaruh pada produksi lahan. Kadar air yang optimum saat panen adalah kondisi lembab.

Kata kunci-kadar air tanah; produksi; salibu; tinggi pemotongan; varietas
\end{abstract}

\section{PENDAHULUAN}

Padi merupakan salah satu produk pertanian yang paling dibutuhkan karena merupakan sumber makanan pokok sebagian masyarakat. Peningkatan produksi padi merupakan salah satu yang harus dilakukan, seiring dengan pertambahan jumlah penduduk. Peningkatan produksi padi dapat dicapai melalui inovasi teknologi, salah satunya yaitu budidaya padi salibu.

Tunas padi yang tumbuh setelah batangnya dipotong ketika di panen, masyarakat Minangkabau menamakannya dengan Padi Salibu. Di sebagian daerah lain ada yang menyebutnya dengan padi suli, padi berlanjut, ratun atau singgang (Jawa) atau turiang (Sunda) dan lain-lain sesuai bahasa daerah setempat. Selama ini padi salibu hanya dijadikan makanan hijauan ternak, karena gabah yang dihasilkan tidak memberikan keuntungan secara ekonomis (Juliadi, 2013).

Padi Salibu merupakan tanaman padi yang tumbuh lagi setelah batang sisa panen ditebas/dipangkas, tunas baru akan muncul dari buku yang ada didalam tanah. Tunas akan mengeluarkan akar baru sehingga suplay unsur hara tidak lagi tergantung pada batang lama tapi melainkan pada tunas baru. Tunas ini bisa membelah atau bertunas lagi seperti padi tanaman pindah biasa, hal inilah yang membuat pertumbuhan dan produksinya bisa sama atau lebih tinggi dibanding dengan tanaman pertama (ibunya). Pertumbuhan tunas setelah dipotong sangat dipengaruhi oleh adanya ketersedian air tanah. Untuk mengimbangi kebutuhan unsur hara pada masa pertumbuhan anakan padi salibu perlu dilakukan pemupukan yang cukup, terutama pada unsur hara nitrogen (Surowinoto, 1980; Juanda, 2016).

Adapun keuntungan yang dapat didapatkan dari penerapan Padi salibu antara lain: (a) biaya produksi jauh lebih rendah karena tidak perlu melakukan pengolahan tanah dan penanaman padi ulang, (b) pupuk yang dibutuhkan lebih sedikit, yaitu setengah dari dosis yang diberikan pada tanaman utama, (c) umur panen relatif pendek, dan (d) hasil dapat meningkatkan produktivitas (Susilawati et al. 2012). Hasil penelitian Juanda (2016) adalah budidaya padi salibu mampu meningkatkan indek panen (IP) berkisar 0,5 s/d 1/tahun, dan meningkatkan produktivitas: 3-6 ton gabah/ha/tahun.

Pada budidaya padi salibu ada factor-faktor yang mempengaruhi antara lain; 1) tinggi pemotongan batang sisa panen, 2) varietas, 3) kondisi air tanah setelah panen, dan 4) pemupukan (Edirman, 2012). Menurut Rong et al. (2009); Susilawati et al. (2012), pemotongan yang pendek mempercepat keluarnya tunas ratun. Tinggi pemotongan yang menyisakan 2-3 ruas, merupakan pemotongan optimal yang dapat meningkatkan vigor ratun dan mengoptimalkan produksi biji pada malai ratun (Vergara et al. 1988; Susilawati et al. 2012). 
Kondisi air tanah setelah panen akan mempengaruhi pertumbuhan tunas setelah pemotongan, yang secara langsung akan menentukan produksi padi salibu tersebut. Pengelolaan yang tidak tepat terhadap tanaman induk pada budidaya padi salibu maka akan menghambat perkembangan tanaman padi salibu tersebut. Penelitian ini bertujuan untuk mengetahui tinggi pemotongan, varietas, dan kondisi air tanah optimum setetah panen untuk budidaya padi salibu pada daerah Sumatera Barat.

\section{METODOLOGI PENELITIAN}

\section{A. Lokasi Penelitian}

Padi salibu di wilayah Sumatera Barat digolongan menjadi 2 yaitu sengaja dibudidayakan dan tidak sengaja dibudidayakan (tumbuh dengan sendirinya). Untuk mengetahui faktor yang berpengaruh pada produksi padi salibu, maka lokasi yang dipilih merupakan lokasi yang sengaja melakukan budidaya salibu. Lokasi pengamatan dilakukan pada beberapa wilayah di daerah Propinsi Sumatera Barat yaitu Kec. Matur (Kab. Agam), Kec X Koto Singkarak (Kab. Solok), Kec Pariangan (Kab. Tanah Datar), Kec Banuhampu (Kab. Agam), Kec Lima Kaum (Kab. Tanah Datar). Lokasi pengamatan sebagai sampel diambil secara acak, yaitu daerah yang menanam salibu pada saat penelitian dilakukan. Tahapan penelitian disajikan pada Gambar 1.

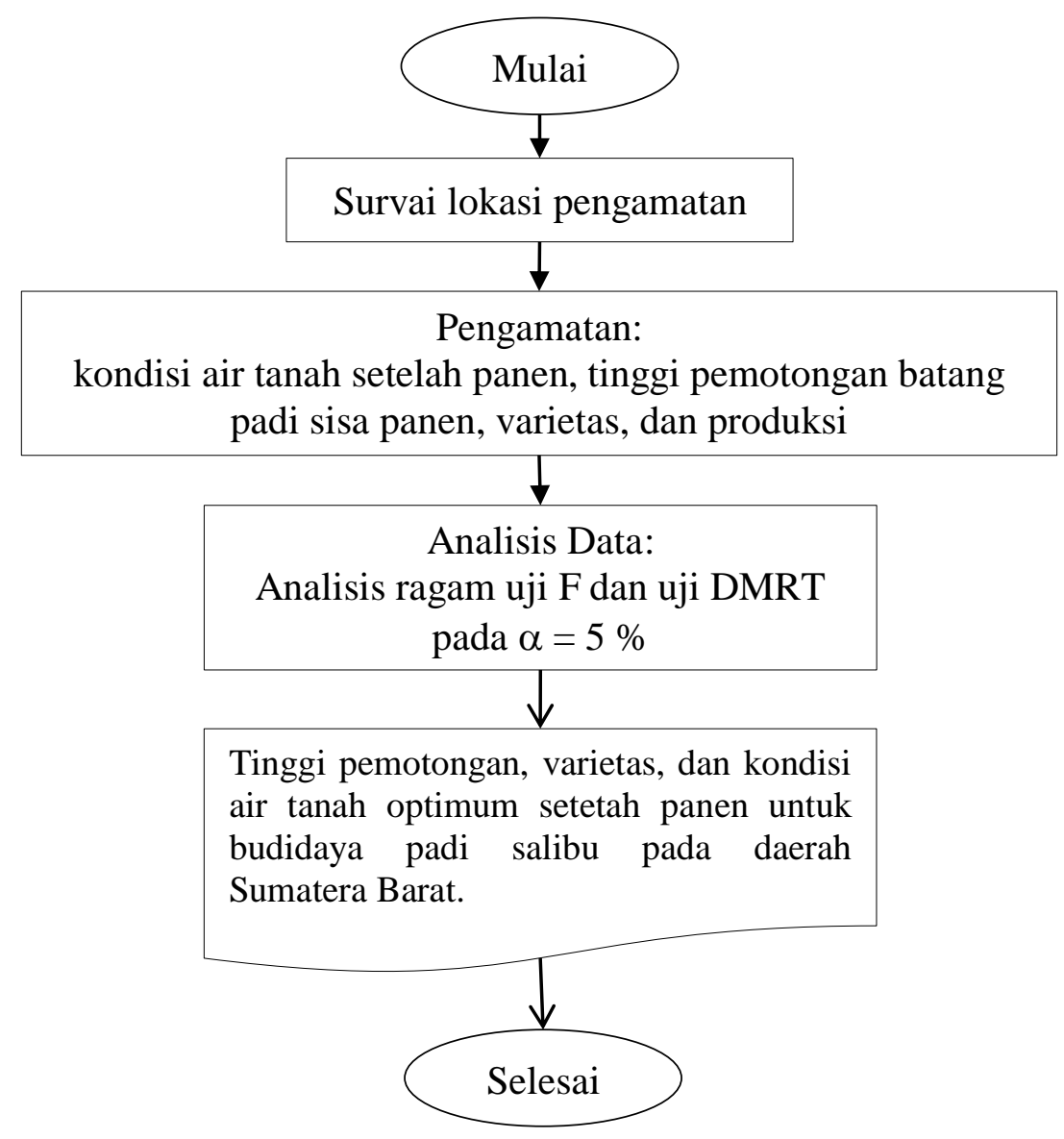

Gambar 1. Tahapan Penelitian

\section{B. Pengumpulan Data}

Pengumpulan data dilakukan melalui metode wawancara dan pengamatan langsung di lapangan. Pengumpulan data dengan metode wawancara dilakukan terhadap parameter varietas, umur panen padi iduk (hari), dan produksi salibu (ton/ha). Sementara pengumpulan data melalui pengamatan langsung dilakukan terhadap parameter kondisi air tanah saat panen padi induk, tinggi pemotongan $(\mathrm{cm})$, dan anakan produktif (batang). 
- Penentuan kondisi air tanah saat panen padi induk dilakukan dengan cara pengamatan secara fisik di lapangan, yaitu dilakukan dengan memijit-mijit tanah dengan menggunakan jari-jari tangan. Indikator kondisi air tanah (basah, lembab, dan kering) sebagai berikut:

- Basah, tanah dapat dibentuk menjadi bola-bola atau gulungan kecil tanpa retak

- Lembab, tanah dipijit dengan ibu jari dan agregat tanah tidak pecah

- Kering, tanah dapat dipecahkan

- Pengukuran tinggi pemotongan padi induk dilakukan dengan cara mengukur tinggi batang padi sisa panen setelah dipotong ulang oleh petani (petani menyebutnya dengan istilah bibit salibu), yang dilakukan langsung pada lokasi pengamatan.

- Jumlah anakan produktif dihitung langsung pada pada lokasi pengamatan, yaitu dengan menghitung jumlah anakan padi yang menghasilkan buah.

\section{Pengolahan Data}

Data hasil pengamatan dianalisis ragamnya dengan uji $\mathrm{F}$ dan dilanjutkan dengan uji DMRT pada taraf nyata $\alpha=5 \%$.

\section{HASIL DAN PEMBAHASAN}

\section{A. Pengaruh Waktu Panen dan Tinggi Potongan Batang Padi Sisa Panen terhadap Jumlah Anakan Padi Salibu}

Tunas padi yang tumbuh setelah batangnya dipotong ketika panen merupakan padi salibu (sebutan masyarakat Minangkabau). Pengembangan teknologi padi salibu menitikberatkan pada teknologi pemotongan padi dimana pemotongan dilakukan sebelum berumur seratus hari atau idelanya sepuluh hari sebelum padi akan dipanen. Hal ini dikarenakan agar pertumbuhan anakan baru dapat menjadi maksimal pertumbuhannya (Balitbangtan, 2015; Wahyuni, 2019). Kegiatan ini dilakukan oleh Balai Pengkajian Teknologi Pertanian (BPTP) Sukarami Kabupaten Solok pada tahun 2013. Potongan ulang batang padi sisa panen pada budidaya Padi Salibu dilakukan apabila setelah panen tanaman utama, tunas baru yang keluar $>70 \%$ dari populasi. Potongan dilakukan secara seragam sehingga tersisa potongan padi 3-5 $\mathrm{cm}$ dari permukaan tanah (Balitbangtan, 2015). Umur panen padi induk dan tinggi tunggul yang tinggal berpengaruh terhadap jumlah anakan yang akan keluar. Data hasil pengamatan nilai rataan anakan produktif pada wilayah pengamatan disajikan pada Tabel 1.

Tabel 1. Deskripsi Padi Salibu Wilayah Sumatera Barat

\begin{tabular}{|c|c|c|c|c|}
\hline \multirow[b]{2}{*}{ Lokasi } & \multicolumn{4}{|c|}{ Parameter } \\
\hline & Varietas & $\begin{array}{l}\text { Umur panen padi } \\
\text { induk (hari) }\end{array}$ & $\begin{array}{l}\text { Tinggi Potongan } \\
(\mathrm{cm})\end{array}$ & $\begin{array}{l}\text { Anakan Produktif } \\
\text { (batang) }\end{array}$ \\
\hline \multirow{3}{*}{$\begin{array}{l}\text { Kec. Matur } \\
\text { (Kab. Agam) }\end{array}$} & Kuriak Kusuik & 135 & $2-4$ & 19 \\
\hline & Kuriak Kusuik & 135 & $3-5$ & 27 \\
\hline & Kuriak Kusuik & 125 & $5-7$ & 24 \\
\hline $\begin{array}{l}\text { Kec Lima Kaum } \\
\text { (Kab. Tanah Datar) }\end{array}$ & Anak Daro & 135 & $3-5$ & 21 \\
\hline \multirow{3}{*}{$\begin{array}{l}\text { Kec Pariangan } \\
\text { (Kab. Tanah Datar) }\end{array}$} & Batang Piaman & 110 & $3-5$ & 29 \\
\hline & Batang Piaman & 120 & $3-5$ & 23 \\
\hline & Batang Piaman & 120 & $5-7$ & 18 \\
\hline \multirow{2}{*}{$\begin{array}{l}\text { Kec Banuhampu } \\
\text { (Kab. Agam) }\end{array}$} & Kuriak Kusuik & 125 & $3-5$ & 25 \\
\hline & Kuriak Kusuik & 125 & $5-7$ & 21 \\
\hline \multirow{2}{*}{$\begin{array}{l}\text { Kec X Koto } \\
\text { Singkarak (Kab. } \\
\text { Solok) }\end{array}$} & Cisokan & 125 & $3-5$ & 27 \\
\hline & Batang Piaman & 120 & $2-4$ & 20 \\
\hline
\end{tabular}

Berdasarkan Tabel 1, dapat dilihat waktu panen dan tinggi potongan batang padi sisa panen pada lokasi penelitian beragam. Umur panen padi induk tergantung pada varietas dan musim. Varietas 
padi yang digunakan oleh petani di wilayah studi merupakan varietas lokal (kuriak kusuik, anak daro, dan cisokan) dengan umur panen 120 hari dan varietas unggul nasional (Batang Piaman) dengan umur panen 135 hari. Menurut Nurnayetti dan Atman (2013), varietas lokal memiliki umur panjang (sekitar 5 bulan) dibandingkan dengan varietas unggul nasional yang berumur pendek (sekitar 4 bulan). Dalam pelaksanaan budidaya Padi Salibu di daerah studi, umur panen padi induk dilakukan petani bervariasi yaitu ada yang tepat pada umur panen varietas padinya dan ada yang lebih cepat 10 hari dari umur panen varietas padi tersebut.

Tinggi potongan yang dimaksud pada objek penelitian ini merupakan tinggi tunggul padi dari permukaan tanah. Tinggi potongan batang padi sisa panen dipengaruhi oleh pengetahuan dan keterampilan petani. Padi salibu merupakan kearifan lokal dalam teknologi padi di Sumatera Barat, sehingga tinggi potongan bervariasi. Hasil analisis varian anakan produktif padi salibu disajikan pada Tabel 2.

Tabel 2. Analisis Varian Pengaruh Waktu Panen dan Tinggi Potongan Batang Padi Sisa Panen terhadap Anakan Produktif

\begin{tabular}{lrrrrr}
\hline & Jumlah Kuadrat & df & Rata-rata Kuadrat & F & \multicolumn{1}{c}{ Sig. } \\
\cline { 2 - 6 } Antar Grup & 319.227 & 7 & 45.604 & 7.945 & 0.000 \\
Dalam Grup & 143.500 & 25 & 5.740 & & \\
Total & 462.727 & 32 & & & \\
\hline
\end{tabular}

Berdasarkan hasil analisis varian (Tabel 2), nilai signifikansi diperoleh sebesar 0.000 yaitu < 0.05 , artinya waktu panen dan tinggi potongan batang padi sisa panen berpengaruh nyata terhadap jumlah anakan produktif. Hasil uji lanjut untuk melihat perbedaan antar perlakuan disajikan pada Gambar 2.

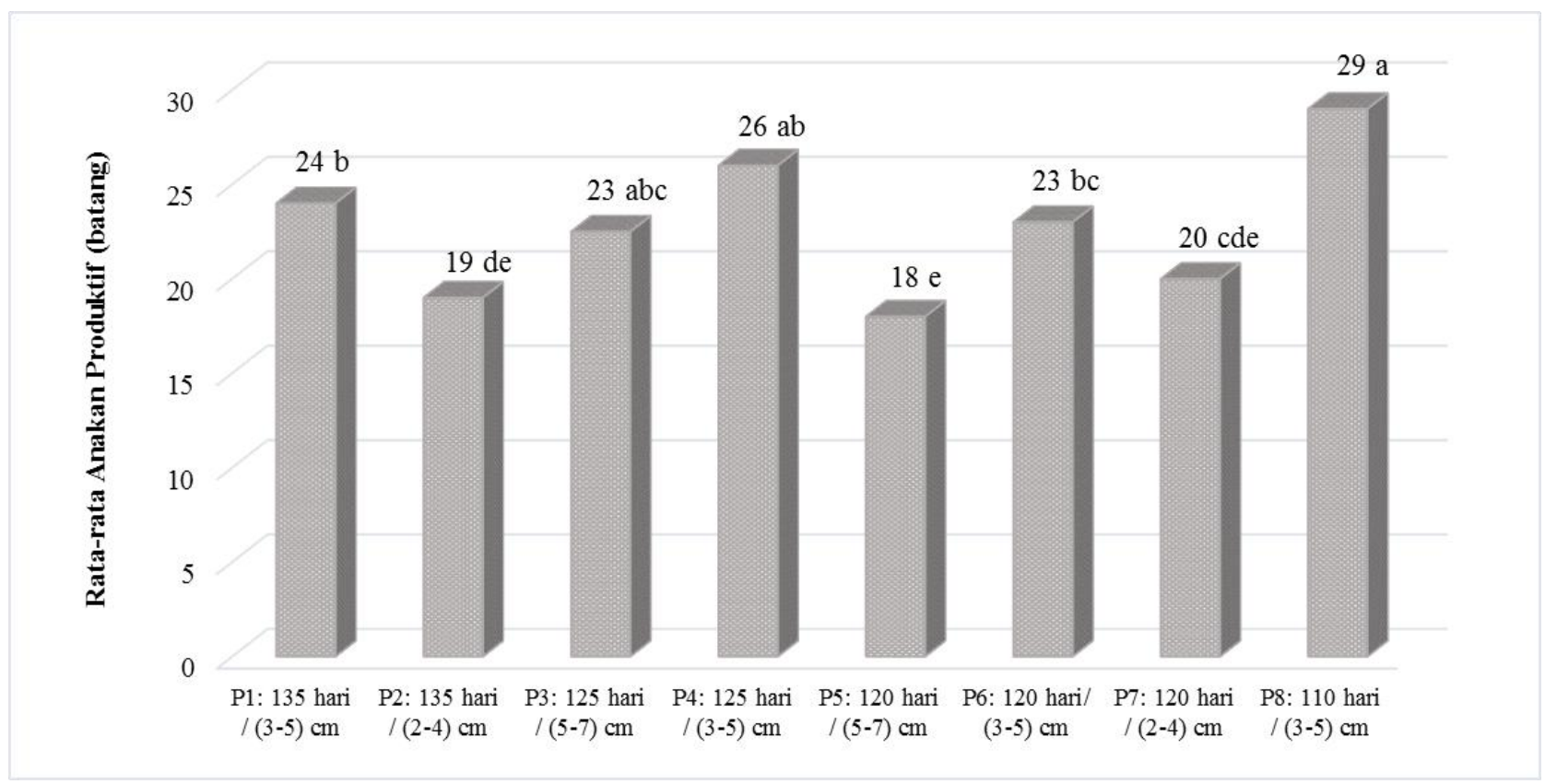

Gambar 2. Jumlah Anakan Produktif Padi Salibu

(nilai-nilai yang diikuti oleh huruf yang sama menunjukkan perbedaan tidak nyata)

Pada Gambar 2 dapat dilihat perlakuan terbaik adalah P8 yaitu umur panen 110 hari dan tinggi potongan 3-5 cm, dengan jumlah rataan anakan produktif sebanyak 29 batang. P5, P6, P7, dan P8 merupakan padi salibu dengan varietas unggul nasional yang mempunyai umur 120 hari, namun dengan mempercepat panen pada umur 110 hari, P8 dapat menghasilkan anakan produktif yang lebih banyak dibandingkan dengan yang lainnya. Begitu juga dengan P1, P2, P3, dan P4 yang merupakan padi salibu varietas lokal yang mempunyai umur 135 hari, namun dengan mempercepat panen pada umur 125 hari, P4 juga menghasilkan anakan produktif lebih banyak dibandingkan dengan varietas 
lokal lainnya. Jika dilihat dari tinggi potongan batang sisa panen yang tertinggal, tinggi potongan yang optimal baik varietas lokal maupun unggul nasional adalah $3-5 \mathrm{~cm}$ dari permukaan tanah. Perlakuan terbaik untuk menghasilkan anakan produktif yang banyak adalah umur panen padi induk dipercepat sepuluh hari sebelum panen yang seharusnya dan tinggi potongan yang optimal dari permukaan tanah sejauh 3-5 cm. Hal ini sejalan dengan rekomendasi Balitbangtan (2015).

\section{B. Pengaruh Kondisi Air Tanah Setelah Panen terhadap Produksi Padi Salibu}

Pertumbuhan tanaman utama padi salibu mempengaruhi dari tingkat keberhasilan budidayanya. Benih yang bermutu mampu menghasilkan pertumbuhan dan perkembangan yang baik hingga ke sistem perakaran yang akan menjadi hal utama dalam keberlangsungan budidaya tanaman salibu. Hasil penelitian yang dilakukan oleh Susilawati et al. (2011) dan Suhartik (2015) terdapat beberapa varietas tanaman padi unggul yang memiliki potensi ratun tinggi yaitu Rokan, Maro, Hipa-4, Hipa-5 Ceva, Inpari 19, Inpari 23, Inpari 24, Inpar 25, Batang Piaman, Inpari 32. Padi salibu di daerah Sumatera Barat menggunakan varietas padi unggul yaitu Batang Piaman. Lokasi pengamatan yang menggunakan varietas Batang Piaman adalah Kec. Paringan (Kab. Tanah Datar).

Selain dari varietas, factor yang perlu diperhatikan adalah kondisi lahan yang harus tetap lembab (kapasitas lapang) pada waktu dua minggu sebelum dan setelah panen (Balitbangtan, 2015). Gambaran waktu panen dan kondisi air tanah sawah pada saat panen di beberapa daerah pengamatan disajikan pada Tabel 2.

Tabel 2. Waktu Panen dan Kondisi Air Tanah Sawah Padi Salibu Wilayah Sumatera Barat

\begin{tabular}{|c|c|c|c|}
\hline \multirow[b]{2}{*}{ Lokasi } & \multicolumn{3}{|c|}{ Parameter } \\
\hline & Waktu Panen & $\begin{array}{c}\text { Kondisi Air Tanah } \\
\text { saat panen }\end{array}$ & $\begin{array}{c}\text { Produksi } \\
\text { (ton/ha) }\end{array}$ \\
\hline \multirow{3}{*}{$\begin{array}{l}\text { Kec. Matur } \\
\text { (Kab. Agam) }\end{array}$} & \multirow{3}{*}{$\begin{array}{l}\text { Sesuai umur padi } \\
\text { Sesuai umur padi } \\
10 \text { hari lebih cepat dari } \\
\text { umur padi }\end{array}$} & Lembab & 6.4 \\
\hline & & Lembab & 7 \\
\hline & & Lembab & 6.2 \\
\hline $\begin{array}{l}\text { Kec Lima Kaum } \\
\text { (Kab. Tanah Datar) }\end{array}$ & Sesuai umur padi & Lembab & 6 \\
\hline \multirow{3}{*}{$\begin{array}{l}\text { Kec Pariangan } \\
\text { (Kab. Tanah Datar) }\end{array}$} & $\begin{array}{l}10 \text { hari lebih cepat dari } \\
\text { umur padi }\end{array}$ & Lembab & 8.2 \\
\hline & Sesuai umur padi & Lembab & 7.8 \\
\hline & Sesuai umur padi & Lembab & 5.4 \\
\hline \multirow{2}{*}{$\begin{array}{l}\text { Kec Banuhampu } \\
\text { (Kab. Agam) }\end{array}$} & $\begin{array}{l}10 \text { hari lebih cepat dari } \\
\text { umur padi }\end{array}$ & Lembab & 6.4 \\
\hline & $\begin{array}{l}10 \text { hari lebih cepat dari } \\
\text { umur padi }\end{array}$ & Lembab & 6.1 \\
\hline \multirow{2}{*}{$\begin{array}{l}\text { Kec X Koto Singkarak } \\
\text { (Kab. Solok) }\end{array}$} & $\begin{array}{l}10 \text { hari lebih cepat dari } \\
\text { umur padi }\end{array}$ & Lembab & 6 \\
\hline & Sesuai umur padi & Lembab & 6.4 \\
\hline
\end{tabular}

Pada Tabel 2 dapat dilihat waktu panen padi induk pada lokasi penelitian tergolong dua macam yaitu sesuai dengan umur padi dan 10 hari lebih cepat dari umur padi. Waktu panen padi induk ditentukan oleh keinginan petani sendiri atau lebih cenderung ditentukan oleh kondisional. Kondisi air tanah saat panen secara umum adalah lembab. Padi induk yang dipanen 10 hari lebih cepat dari umur padinya mempunyai produksi padi salibu lebih banyak.

Data produksi pada Tabel 2 merupakan data produksi lokasi pengamatan. Produksi salibu pada lokasi pengamatan tidak hanya dipengaruhi oleh 3 faktor yang diamati pada penelitian ini (umur panen padi induk, kondisi air tanah saat panen, dan tinggi pemotongan padi induk). Sementara pola perawatan tanaman yang juga mempengaruhi produksi salibu, namun belum dikaji lebih jauh pada penelitian. 


\section{KESIMPULAN}

Waktu panen dan tinggi potongan batang padi sisa panen berpengaruh nyata terhadap jumlah anakan produktif. Untuk menghasilkan anakan produktif yang banyak, maka umur panen padi induk dipercepat sepuluh hari sebelum panen yang seharusnya dengan tinggi potongan dari permukaan tanah sejauh 3-5 cm. Kondisi air tanah yang optimum pada saat panen padi induk adalah lembab.

\section{DAFTAR PUSTAKA}

Abdulrachman et al. 2015. Panduan Teknologi Budidaya Pasi Salibu. Balai Penelitian dan Pengembangan Pertanian. Kementerian Pertanian.

Akhgari, Hassan., Seyyed Ali Noorhosseini Niyaki. 2014. Effects of First Harvest Time on Total Yield and Yield Components in Twice Harvesting of Rice (Oryza sativa L.) in Rasht, Iran. International Journal of Biosciences. Vol. 4, No. 5, p.210-215

[Balitbangtan] Balai Penelitian dan Pengembangan Pertanian. 2015. Panduan Teknologi Budidaya Pasi Salibu. Kementerian Pertanian.

Erdiman. 2012. Teknologi Salibu Meningkatkan Produktivitas Lahan dan Pendapatan Petani. Balai Pengkajian Teknologi Pertanian Sumatera Barat.

Juanda, Boy Riza. 2016. Potensi Peningkatan Produksi Padi dengan Meningkatkan IP (Indek Panen) Melalui Penerapan Teknologi Padi Salibu. Agrosamudra. Jurnal Penelitian. Vol. 3, No. 1, Jan Juni 2016

Nurnayetti dan Atman. 2013. Keunggulan Kompetitif Padi Sawah Varietas Lokal di Sumatera Barat. Jurnal Pengkajian dan Pengembangan Teknologi Pertanian Vol. 16, No.2, Juli 2013: p.102-110. doi:10.21082/jpptp.v16n2.2013.p\%25p

Rong. Z., L. Xiao-ping, Z. Shang, Z. Chuan-ying, J. Zhaowei. 2009. Growth Characteristics of Stem Axiliary Buds on Ratoon Rice. Fujian J. Agric. Sci. 3:21-34.

Suhartik, E., Abdulrachman, Makarim A.K., Widyanto, Indra, Pratiwi G.R., Rifki, Trisnaningsih, Mansur. A., Sukmana, C., Darmawan, A., Pulung. 2015. Studi Potensi Ratun Sistem Salibu pada beberapa Varietas Padi Sawah. Laporan Akhir Tahun. Balai Besar Penelitian Tanaman Padi.

Susilawati, B.S. Purwoko, H. Aswidinnoor, E. Santosa. 2012. Tingkat Produksi Ratun Berdasarkan Tinggi Pemotongan Batang Padi Sawah Saat Panen. J. Agronomi. Indonesia 40:1-7

Vergara, B.S., F.S. Lopez, J.S. Chauhan. 988. Morphology and physiology of ratoon rice. p. 3-40. In W.H. Smith, V. Kumble, E.P. Cervantes (Eds.) Rice Ratooning. IRRI, Los Banos, Philippines.

Wahyuni, Sri., Zulvera, Heri Bachrizal Tanjung, Ernita Arif. 2019. Hubungan Karakteristik Inovasi dan Kearifan Lokal terhadap Keberlanjutan Penerapan Teknologi Padi Salibu di Kabupaten Tanah Datar, Sumatera Barat. Jurnal Penyuluhan. Vol. 15, No.1, p. 134-143. doi:10.25015/penyuluhan.v15i1.21237 